\author{
POMPEO SUMA $^{1 *}$ - SALVATORE NUCIFORA ${ }^{1}$ - VIRGILIO CALECA ${ }^{2}$ - GABRIELLA LO VERDE ${ }^{2}$ \\ FRANCESCO TORTORICI ${ }^{2}$ - CARMELO RAPISARDA ${ }^{1}$ - SALVATORE BELLA ${ }^{3}$
}

\title{
A REVIEW ON INTRODUCED ALIEN INSECT PESTS AND THEIR ASSOCIATED PARASITOIDS ON EUCALYPTUS TREES IN SICILY $\left({ }^{1}\right)$
}

\author{
(') Università degli Studi di Catania, Dipartimento di Agricoltura, Alimentazione e Ambiente (Di3A), via Santa Sofia \\ 100, 95123 Catania, Italy \\ ${ }^{(2)}$ Università degli Studi di Palermo, Dipartimento di Scienze Agrarie, Alimentari e Forestali (SAAF), viale delle \\ Scienze, Edificio 5, 90128 Palermo, Italy. \\ $\left(^{3}\right)$ CREA-OFA - Consiglio per la ricerca in agricoltura e l'analisi dell'economia agraria, Centro di ricerca olivicoltu- \\ ra, frutticoltura e agrumicoltura, Corso Savoia 190, 95024 Acireale, Catania, Italy. \\ (") Corresponding author (e-mail: suma@unict.it).
}

Suma P., Nucifora S., Caleca V., Lo Verde G., Tortorici F., Rapisarda C., Bella S. - A review on introduced alien insect pests and their associated parasitoids on Eucalyptus trees in Sicily.

A review is reported in the present paper on invasive alien insects introduced in Sicily on Eucalyptus trees, together with unpublished results from recent surveys. As to the latter ones, observations were conducted especially on Thaumastocoris peregrinus (Carpintero \& Dellapé) (Hemiptera, Thaumastocoridae), the most recently introduced species. Overall, eight alien insect pests have been accidentally introduced in the island on Eucalyptus, belonging to the orders Hemiptera (Aphalaridae, 2 spp.; Thaumastocoridae, 1 sp.), Coleoptera (Cerambycidae, 2 spp.; Curculionidae, 1 sp.) and Hymenoptera (Eulophidae, 2 spp.). Two encyrtid parasitoids, Avetianella longoi Siscaro and Psyllaephagus bliteus Riek, obtained from Phoracantha spp. and Glycaspis brimblecombei Moore respectively, and Closterocerus chamaeleon (Girault) (Hymenoptera, Eulophidae) attacking Ophelimus maskelli (Ashmead), are also reported. Details on current distribution, host plants, morphological and biological remarks are given for each species.

KeY WoRDS: Alien insects; eucalypts; South Italy; psyllids; gall wasps; bronze bug.

\section{INTRODUCTION}

Eucalyptus trees are the most widely planted hardwood trees in the world, representing one of the main sources of biomass (Teulieres \& MARQue, 2007). Native to the Australian continent, these species are widely diffused in the whole Mediterranean region not only as ornamental but also as timber trees. According to the Regional Forest Agency of the Sicily administrative region (South Italy), eucalyptus trees cover about 35,000 ha in this island (SAPORITO, 2006).

Despite continuous efforts to limit the accidental introduction of exotic plant and animal pests, a few alien insects feeding on Eucalyptus have been detected in Sicily so far. Although for most of them the mode of introduction has not been established, from the analysis of the different temporal and spatial patterns it is possible to assume that their occurrence is mainly linked with the increased trade of these plant species. In detail, eight species of insect pests have been recorded to infest eucalyptus trees in Sicily since mid of the 70's (Tab. 1); three of them belong to the order Hemiptera, three to the order Coleoptera and two are Hymenoptera. Some notes about their presence in Sicily are reported herein, pointing out their impact on the host plant.

\footnotetext{
${ }^{1}$ Original scientific contribution presented and discussed at the National Symposium on "Health status of Eucalyptus plantations in Italy", Oristano (Centro Congressi Hotel Anfora, Tramatza) - Italy, March 24-25, 2017.
}

\section{HEMIPTERA}

Among insects, the order Hemiptera account for many of the economically significant eucalyptus pests, damaging plants by feeding on phloem sap. Psyllids and true bugs are worth to be mentioned here within this insect group.

\section{FAMILY APHALARIDAE}

Plants of the genus Eucalyptus L'Hér. are known to host more than 250 species of Psylloidea worldwide, of which the greatest part in the family Aphalaridae and a few remaining ones in the Triozidae and Psyllidae (OUVRARD, 2017). Almost all of these species are native to Australia; some of them have been following the artificial diffusion of their host plants over the last decades and have been consequently spread all over the world, occasionally becoming invasive pests in Eucalyptus production areas of many continents (BURCKHARDT et al., 1999).

In Italy, five species of psyllids have been recorded till now on Eucalyptus, all of them belonging to the family Aphalaridae. The first report dates back to about 35 years ago and concerns Ctenarytaina eucalypti (Maskell) (CAvalcaselle, 1982), which remained for almost 20 years the only species known to feed on Eucalyptus spp. in Italy. Recently, over the last fifteen years, four other species have been reported almost at the average rate of one every four years: Ctenarytaina spatulata Taylor (Costanzi et al., 2003), Blastopsylla occidentalis Taylor (LAUdonia, 2006), Ctenarytaina peregrina Hodkinson (MIFsUD et al., 2010, who report unpublished data by 
Tab. 1 - Alien insects detected in Sicily on Eucalyptus trees during the last 40 years.

\begin{tabular}{|c|c|c|}
\hline PESTS & ITALY & SICILY \\
\hline Phoracantha semipunctata (F.) (Coleoptera: Cerambycidae) & TASSI, 1969 & ROMANO \& CARAPEZZA, 1975 \\
\hline Ctenarytaina eucalypti (Maskell) (Hemiptera: Aphalaridae) & Cavalcaselle, 1982 & RAPISARDA, 1998 \\
\hline Leptocybe invasa Fisher \& La Salle (Hymenoptera: Eulophidae) & VIGGIANI et al., 2002 & BeLla \& Lo Verde, 2002 \\
\hline Ophelimus maskelli (Ashmead) (Hymenoptera: Eulophidae) & ARZONE \& Alma, 2000 & BeLla \& Lo Verde, 2002 \\
\hline Phoracantha recurva Newman (Coleoptera: Cerambycidae) & SAMA \& BocchinI, 2003 & MAZZEO \& Siscaro, 2007 \\
\hline Glycaspis brimblecombei Moore (Hemiptera: Aphalaridae) & LAUDONIA \& GARONNA, 2010 & LO VERDE et al., 2011 \\
\hline Thaumastocoris peregrinus Carpintero \& Dellapé (Hemiptera: Thaumastocoridae) & LAUDONIA \& SASSO, 2012 & SuMA et al., 2014 \\
\hline Gonipterus scutellatus Gyllenhal (Coleoptera: Curculionidae) & ARZone, 1976; SAMPò, 1976 & MAzZA et al., 2015 \\
\hline PARASITOIDS & HOST & \\
\hline Avetianella longoi Siscaro (Hymenoptera: Encyrtidae) & P. semipunctata & SISCARO, 1992 \\
\hline Closterocerus chamaeleon (Girault) (Hymenoptera: Eulophidae) & O. maskelli & Rizzo et al., 2006 \\
\hline Psyllaephagus bliteus Riek (Hymenoptera: Encyrtidae) & G. brimblecombei & CALECA et al., $2011 a$ \\
\hline
\end{tabular}

Cocquempot \& Costanzi) and Glycaspis brimblecombei Moore (LAUdONIA \& GARONNA, 2010).

Apart from its native areas in Australia, the "blue gum psyllid", C. eucalypti, occurs also in New Zealand, North and South America, Papua New Guinea, South Africa, Sri Lanka and is widely diffused in Europe (CoNCI et al., 1996; BurCKHARDT, 1998; RAPISARDA, 1998; Hollis, 2004; DE QUeIROZ SANTANA \& BURCKHARDT, 2007; Mifsud et al., 2010; BurcKHARDT \& QueIroz, 2012; OuvRARD et al., 2015). Among the Eucalyptus-feeding psyllids, it is the one known for the longest time as pest outside its native regions. It is efficiently controlled by the parasitoid Psyllaephagus pilosus Noyes (Hymenoptera: Encyrtidae), which is successfully used in biocontrol programs of the psyllid (Hodkinson, 1999; CHAUZAT et al., 2002).

An almost similar but rather limited geographical distribution is shown by $C$. spatulata, which is recorded from New Zealand, North and South America, Europe, in addition to its native areas of Australia (BRENNAN et al., 1999; CostANZI et al., 2003; Hollis, 2004; VALENTE et al., 2004; De Queiroz Santana \& Burckhardt, 2007; Bouvet \& BURCKHARDT, 2008; Mifsud et al., 2010; O'CONNOR \& MALUMPHY, 2011; BurcKHARDT \& QueIroz，2012; GREENSLADE, 2016). In Italy, no records of this species are available till now out from the North-Western region Liguria, thus confirming its limited dissemination capacity and the rather secondary pest role that this species plays on Eucalyptus plantations throughout its distribution area. Unlike the previous two species, the eucalypt shoot psyllid B. occidentalis is recorded also from Africa, Middle East, Hawaii Islands and China (Hollis, 2004; AYTAR, 2007; DE QueIroz SANTANA \& BurckHardT, 2007; Dzokou et al., 2009; SPODEK et al., 2015), apart from Australia, New Zealand, America, and Europe (HALBert et al., 2001; Bouvet et al., 2005; PÉrEZ-OTERO et al., 2011; MARTINEZ et al., 2014; OuVRARD, 2017). Such as all other species of the genus Blastopsylla Taylor, this psyllid feed on young leaves and growing tips of the host plants, producing a copious amount of flocculent wax that allows the insect presence to be easily detected on infested trees. C. peregrina, known till now to live only on Eucalyptus parvula L.A.S. Johnson \& K.D. Hill, has been reported only from Great Britain and Ireland, where it has been described by
HODKINSON (2007), and also (though almost informally and with no geographical specification) from France and Italy (Mifsud et al., 2010); compared to the previous species, it seems to be still poorly known and in need of further investigation aimed at better understanding its geographical origin and distribution.

The last arrived, the red gum lerp psyllid G. brimblecombei, is the only Eucalyptus-feeding species presently occurring in Italy whose nymphs form the so called "lerp", a sort of characteristic shield-like conical white waxy covering, probably used by the nymphs for protection against natural enemies. It has a wide diffusion in many continents: Australia, Madagascar, Mauritius, North and South America, South Africa (OuvRARD, 2017). In Europe, it first appeared in the Iberian Peninsula about ten years ago (Hurtado \& Reina, 2008; VAlEnTE \& Hodkinson, 2009) and very rapidly (and almost contemporaneously) it has been recorded during the following years in Italy (LAUDONIA \& GARONNA, 2010) and in other countries of the Mediterranean Basin (Bella, 2013; Bella \& RAPISARDA, 2013; MALUMPHY et al., 2013; Reguia \& Peris-Felipo, 2013; Bella, 2014; Ben Attia \& RAPISARDA, 2014; DHAHRI et al., 2014). The first findings of this species in Sicily and the circum-Sicilian islands date back to spring 2011 (Lo VERDE et al., 2011). A fast mapping of the psyllid's rapid spread in this territory has been easily allowed by the visibility of its infestations, due to the presence of the mentioned white lerps. These follicles gave the possibility to ascertain how in a few months, and already in the summer of 2011, the psyllid was widely present in all Sicilian provinces, allowing also to hypothesize an important role played by the passive component in its dissemination.

\section{FAMILY THAUMASTOCORIDAE}

Another exotic sap-sucking insect pest feeding on eucalyptus leaves was recently intercepted in Sicily, namely Thaumastocoris peregrinus (Carpintero \& Dellapé) (Hemiptera: Thaumastocoridae). This species, native to Australia like its host plant, quickly invaded new areas in about ten years (NOACK \& Rose, 2007; NOACK et al., 2009) and it is by now considered a serious pest in Australia, South Africa, South America and New Zealand (JACOBS \& 
NeSER, 2005; NoACK \& COVIElla, 2006; MARTINEZ-Crosa, 2008; WILCKEN et al., 2010; GILIOMEE, 2011; IDE et al., 2011; Soliman et al., 2012; Sopow et al., 2012). In late 2011, it was recorded for the first time in Europe (LAUDONIA \& SASSO, 2012) infesting several species of Eucalyptus in Italy (Latium region); later on, it was reported also from Portugal (GARCIA et al., 2013) and, in winter 2014, from Sicily (Suma et al., 2014). The leaf damage is due to the bug feeding, that induces silvering chlorosis followed by the bronzing and drying of leaves. Severe infestations lead to leaves drop and severe canopy thinning, up to the branch dieback. Since its discovery in Sicily and in order to estimate its diffusion in the region, an accurate monitoring activity has been carried out. Currently, its presence is well documented in three main areas of this region: two in the East, in an urban area of the town of Catania and in the coastal zone of the Messina province, and one in the West side of the island, in a suburban area of the town of Palermo. Contrariwise, it has not been detected in the inland till now. In each prospected site, and as an "active collecting method" (sensu GROOTAERT et al., 2010), an average of 10 E. camaldulensis trees were sampled from March 2014 to April 2015, collecting 10 twigs/tree, approximately 40 $\mathrm{cm}$ in length, that were subsequently examined in the lab under the microscope. From late June until January, all the bug instars were simultaneously present along the twigs and especially on the leaves from the previous years (i.e. not in the younger ones); mature copulating adults were often observed. During our survey, the infestation by the bronze bug was often recorded in association with that one by the red gum lerp psyllid G. brimblecombei (Fig. I). Clusters of black egg capsules of the bronze bug are often laid in the proximity of the leaf depressions (e.g. those associated with the infestations by the gall wasp Leptocybe invasa Fischer $\&$ La Salle) and singly, between the valves of E. camaldulensis fruits (Figs II and III). The infested trees showed only a slight discoloration of leaves caused by the feeding activity of $T$. peregrinus (Fig. IV) and, considering that the same plantations were regularly monitored from 2009 in the

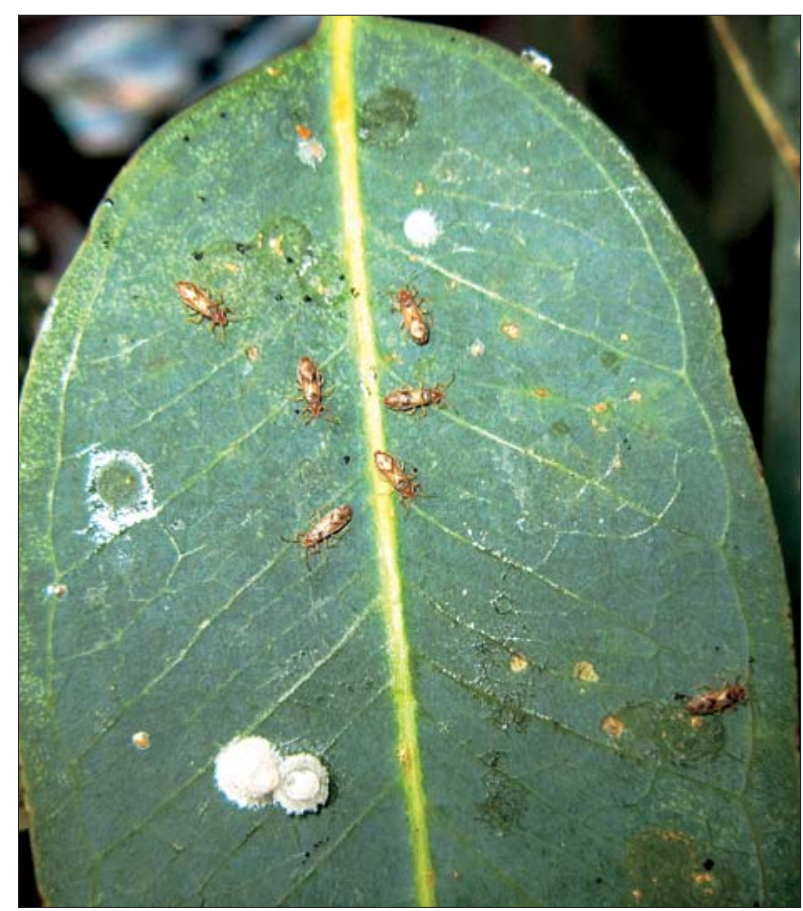

Fig I - Adults of $T$. peregrinus on leaf of $E$. camaldulensis in association with the red gum lerp psyllid G. brimblecombei.

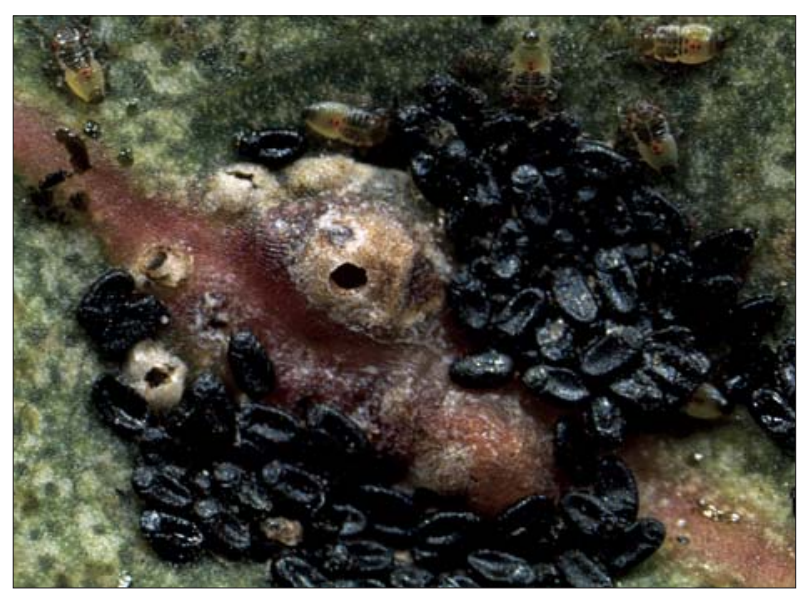

Fig II - Clusters of black egg capsules of T. peregrinus laid in proximity of the leaf depressions caused by the gall wasp $L$. invasa.

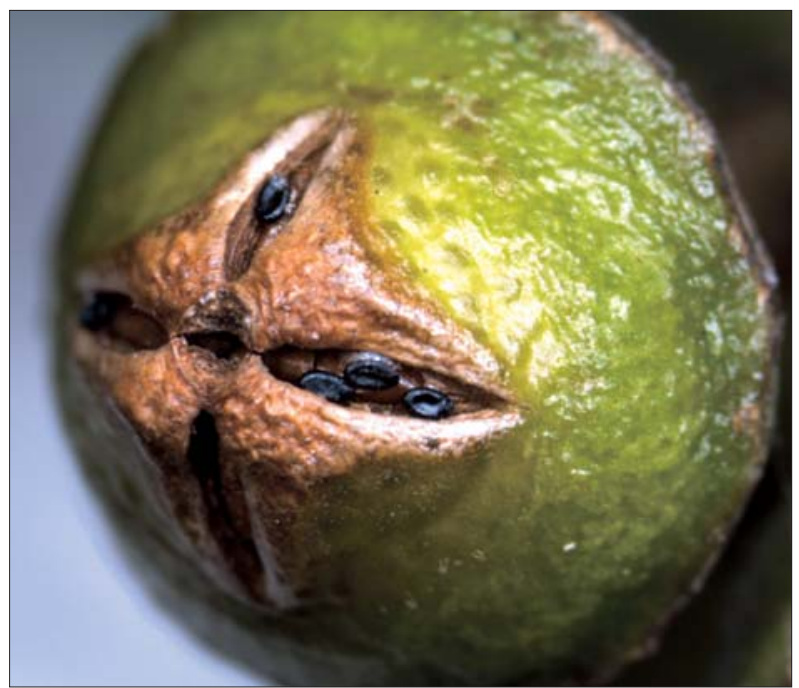

Fig III - Egg capsules of T. peregrinus laid between the valves of E. camaldulensis fruits.

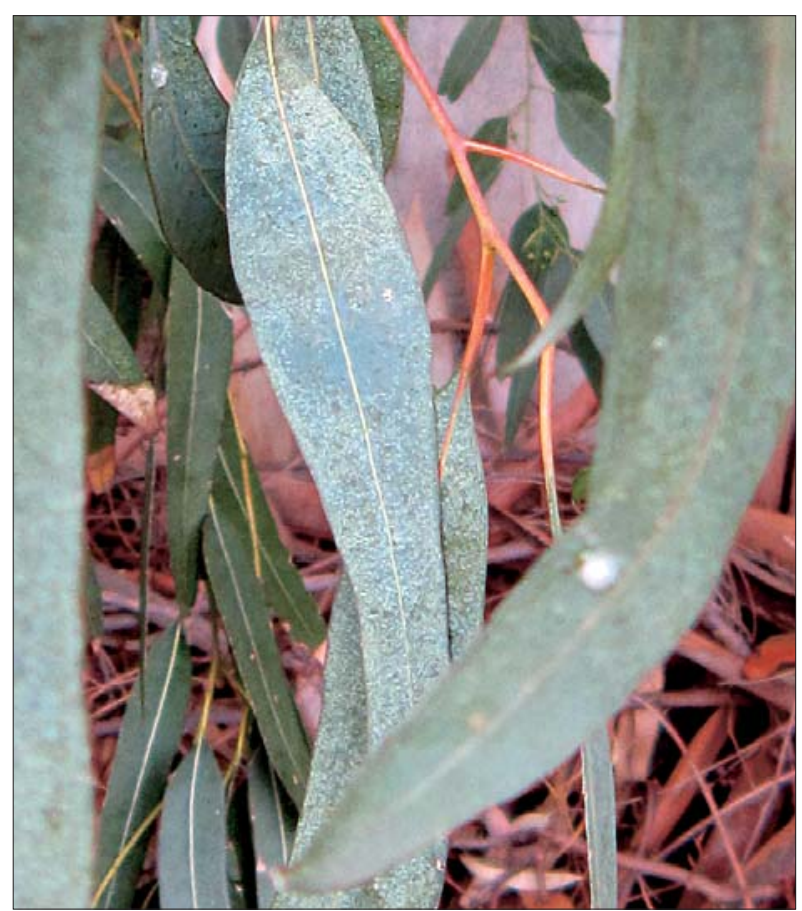

Fig IV - Effect of the feeding activity of T. peregrinus on the leaves of E. camaldulensis. 
framework of the National Research Programme "GEISCA", it is highly assumable that the bug just arrived at that time. During the same prospecting period, yellow sticky traps $(15 \times 15 \mathrm{~cm})$, as "passive collecting method", were also installed in the main infested areas at approximately $2.00 \mathrm{~m}$ height, in order to investigate the usefulness of this tool within a monitoring activity. Starting from late May, it was possible to detect adults of the bug stuck on the traps, whereas juvenile instars, although at a lesser quantity, were always detected starting from late June.

\section{COLEOPTERA}

Among this Insects order, both longhorn beetles and weevils (respectively living on wood and as defoliators) have been introduced in Sicily during recent years.

\section{FAMILY CERAMBYCIDAE}

The first alien insect species recorded on eucalyptus trees in Sicily is the wood-borer beetle Phoracantha semipunctata (Fabricius), a longhorn beetle whose spread was noticed in many Sicilian eucalyptus woods by the mid of the 70' (ROMANO \& CARAPEZZA, 1975). It was first introduced from Australia into South Africa in 1890s, in wooden railway sleepers, and in 1917 it colonized eucalyptus plantations in Argentina, from where it arrived later in Uruguay, Chile and Peru. Probably during the Second World War, it reached some Mediterranean countries (e.g. Israel, Lebanon, Egypt, Tunisia, etc.) and its first findings in Europe occurred in Sardinia (TASSI, 1969; PIRAS et al., 1970). During the 80's it was reported from Portugal, Spain, South France and Corsica (CADAHIA, 1980; CADAHIA \& Ruperez, 1980; Orousset, 1984).

The congeneric species, $P$. recurva Newman, native to Australia and Papua - New Guinea (WANG, 1995), was first recorded in Mediterranean Basin in a Spanish territory of the north-western Maghreb (i.e. Ceuta) (RuIz \& BARRANCO, 1998); in Italy, it was then reported in 2003 (SAMA \& BocCHINI, 2003), even if the correct identification of specimens of $P$. recurva collected in Calabria and misidentified as $P$. semipunctata allowed to ascertain the occurrence of the species from 1992 (PALMERI \& CAMPOLO, 2006). More recently, $P$. recurva was recorded also in Sardinia (CILlo et al., 2006) and Sicily (MAZZEO \& SisCARO, 2007; ROMANO, 2007).

Although the two Phoracantha Newman species share the same ecological niche and have an almost similar morphology, they can be differentiated based on the stains pattern on the elytrae (mostly cream to yellowish in $P$. recurva, with dark brown areas primarily limited to the rear third of the elytra, but dark brown in P. semipunctata, with a cream area in the middle), the chaetotaxy of antennal segments (which have dense setae in $P$. recurva adults but only a few or none in $P$. semipunctata), and the dense spines which occur on the front dorsal side of hind femora in $P$. recurva (WANG, 1995; PALMERI \& CAMPOLO, 2006). P. semipunctata larvae have temples with a broad ferruginous cuneiform band behind the base of antennae and a uniform setose area, with distinctly central setae at each median lobe, at the $10^{\text {th }}$ abdominal tergite; in $P$. recurva, the cuneiform band is absent and the $10^{\text {th }}$ abdominal tergite has only sparse hairs and a pair of long setae on the median lobe.

The biology of the two Phoracantha species is subtly different. In California, four years after its introduction, $P$. recurva has largely replaced $P$. semipunctata, increasing from $0.1 \%$ of the total Phoracanta spp. population in 1995 to $74 \%$ in 1997 (PAINE et al., 2000). Adults of these species attack large stems and branches that are dying or have died recently; attacks may also occur on living Eucalyptus trees, especially when they are stressed by drought, or on freshly cut logs. The life cycle is annual but can also involve two partially overlapping generations. Adults emerge in early spring and after mating, females lay their egg under loose bark or in bark crevices or branch stubs (WANG, 1995; PAINE et al., 2000). Eggs are laid in clusters of 10-40 each and hatch in 6 to 15 days, depending on the ambient temperature and the larvae bore through or under the bark and mine along the cambium of the attacked trees. At maturity, they construct a vertical pupal chamber into the heartwood and an exit hole that is plugged with frass. Adults live for up to 3 months, they are nocturnal and, during the day they hide under the bark. Yellowing of the crown, apical dieback, resination, debarking and production of oval emergence holes, which appear through the bark, are the main symptoms of the attack by the two longhorn beetles. The egg parasitoid Avetianella longoi Siscaro (Hymenoptera: Encyrtidae), native to Australia, is the most important parasitic wasp used to control the two species of Phoracantha, and this is up to now the sole natural enemy of these beetles recorded in Sicily. However, results obtained in California and South Africa, indicate that the parasitoid is less effective against $P$. recurva than $P$. semipunctata (PAINE et al., 2000; TRIBE 2003).

\section{FAMILY CURCULIONIDAE}

The third coleopteran species recorded on eucalyptus trees in Sicily is the snout beetle Gonipterus scutellatus Gyllenhal. It is a species native to Australia, which feeds on a wide range of host trees, mainly belonging to the genus Eucalyptus, and the ornamental ones are considered to be most at risk (CADAHIA, 1986). It is an important defoliator of eucalyptus in several parts of the world but, fortunately, biological control by using the egg parasitoid Anaphes nitens (Girault) (Hymenoptera: Mymaridae), claimed in France, Italy and Spain, had successfully reduced its attacks (CADAHIA, 1986). Eggs of G. scutellatus are laid attached to the leaves, on both surfaces, in greyish capsules containing about 8-10 eggs each. The larvae, yellowishgreen with black marks, are more easily distinguished visually than the adults. The latter ones are grey-brown weevil, with a light, transverse band on each elytra, not readily discernible visually from $G$. gibberus Boisduval, though distinctive details of the genitalia can allow their discrimination (Rosado-Neto \& Marques, 1996). Although this weevil does not seem to be a threat for the Sicilian eucalyptus trees, some infested individuals of E. globulus were recently recorded in the province of Catania, where defoliations probably caused by this insect have been visible since 2012 (MAZZA et al., 2015). Signs of its presence on infested trees can be detected from May to September, when it is possible to observe the damaged leaves as well as the egg capsules and larvae of the insect. These last ones can only eat on the leaf surface, leaving characteristic tracks, while adults chew the leave edges giving them a ragged, scalloped appearance.

\section{HYMENOPTERA}

\section{FAMILY EULOPHIDAE}

Two Eucalyptus gall wasps, Leptocybe invasa Fisher \& La Salle and Ophelimus maskelli (Ashmead), are currently spread in several countries of the Mediterranean Basin and 
were detected on eucalypts in Sicily, about fifteen years ago (BELla \& Lo VerDE, 2002). They have been reported also from Africa, Asia and North America (MendEL et al., 2017), whereas L. invasa distribution includes also South America (CosTA et al., 2008; AQUINO et al., 2011). Recently, molecular analyses suggested that L. invasa is a complex of two cryptic species (NUGNES et al., 2015): the first one being recovered in the Mediterranean region and South America, the second from China (Mendel et al., 2017).

Ophelimus maskelli galls cause serious defoliation to $E$. camaldulensis both on adult trees and on young plantations, whose growth rate is negatively affected (MENDEL et al., 2004; Protasov et al., 2007). Leptocybe invasa induces plurilocular galls on the stems, shoots, petioles and mid-rib of the leaves, high infestations can cause heavy defoliation (MENDEl et al., 2004; KARUNARATNE et al., 2010).

Several studies have shown how both gall wasps currently appear to be successfully controlled by various biological control agents, especially hymenopteran parasitoids. Among them, three species were in fact released in Israel for the biological control of $O$. maskelli: Closterocerus chamaeleon (Girault) (Eulophidae), Stethynium ophelimi Huber and S. breviovipositor Huber (Mymaridae) (Mendel et al., 2007) and the first one was also released in Italy (LAUDONIA et al., 2006; Rizzo et al., 2006, 2015). As regards L. invasa biological control, four species of parasitoids were released in Israel as well: Megastigmus zvimendeli Doĝanlar, M. lawsoni Doĝanlar (Torymidae), Selitrichodes kryceri Kim \& La Salle and Quadrastichus mendeli Kim \& La Salle (Eulophidae) (Protasov et al., 2008) but no information is available till now about their presence in Sicily.

\section{DISCUSSION}

In general, no substantial damage has been inflicted so far to eucalyptus trees by the insect pests recorded in Sicily. Certainly, some of them require constant supervision and monitoring in order to avoid they become exceedingly injurious. In particular, over their whole distribution area, all five psyllids recovered in Italy till now are oligophagous on various plant species of the genus Eucalyptus. Unlike what has been reported in other areas of the world, in most cases attacks by $G$. brimblecombei in Sicily have not produced serious problems to infested plants, apart from the aesthetic damage and some dieback; especially, no obvious signs of decay have been noted. By sure, the relatively low impact of this alien psyllid on Sicilian Eucalyptus plantations is largely linked to the spontaneous introduction and naturalization of its parasitoid, $P$. bliteus, found in almost all Sicilian sites where the psyllid has been detected at only a very short (or none) time distance from the first records of the pest (CALECA et al., 2011a; MARGIOTTA et al., 2017). In this context, the importance shown by this parasitoid during the last years in reducing infestations by the psyllid in Sicily has stimulated a study on the effects of some ecological parameters (especially altitude and climate) on the distribution and density of the encyrtid wasp and on its parasitic efficacy (CALECA et al., 2018).

As regards to the presence of the bronze bug in Sicily, it seems to be premature to claim about its harmfulness for the host plant. Up to now, no severe infestations were recorded in the main surveyed areas of the island and the fortuitous introduction and successful establishment in Sicily of its main biocontrol agent, the ooparasitoid
Cleruchoides noackae Lin \& Huber (Hymenoptera: Mymaridae), would be highly desirable. Interestingly, although deeper investigations are still in progress, by comparing data obtained from both the monitoring methods adopted, it is assumable that sticky traps have the potential to satisfactorily estimate the bug populations and thus they can be effectively employed as a time-efficient method for sampling $T$. peregrinus infestations.

About the wood-boring beetle species, although both $P$. recurva and $P$. semipunctata have been included by WANG (1995) among the Phoracantha species living on dead or declining trees, $P$. recurva has been found abundant also on living plants in Spain (BERCEDO PARAMO \& BAHILlO DE LA PueBLA, 1999), showing how this species could have a huge impact on its host plant health. It is important to highlight as in some Mediterranean countries (Italy and Portugal) the oophagous encyrtid parasitoid A. longoi was detected in association with $P$. recurva and its presence seems to play an important role in maintaining beetle populations stable (LONGO et al., 1993).

Finally, in relation to the two Eucalyptus gall wasps, recent studies carried out after the release of the parasitoid C. chamaeleon in Sicily showed its high efficacy in reducing $O$. maskelli populations. Its establishment, spreading speed and the observed discontinuous pattern of dispersal showed the occurrence of both long and short distance dispersal mechanisms (CALECA et al., 2011b).

\section{ACKNOWLEDGEMENTS}

This research was partially supported by the project "Insects and globalization: sustainable control of exotic species in agroforestry ecosystems (GEISCA)", funded by the Italian Ministry for Education, University and Research (PRIN 2010/2011, project 2010CXXHJE_004).

\section{REFERENCES}

Arzone A., 1976 - Un nemico dell'eucalipto nuovo per l'Italia. - Apicolt. mod., 67: 173-177.

Arzone A., Alma A., 2000 - Eulofide galligeno dell'eucalipto in Italia. - Inf.tore fitopat., 50: 43-46.

Aquino D.A.D., Botto E., Loiácono M., Pathauer P., 2011 - "Eucalyptus Gall Wasp" Leptocybe invasa Fischer \& Lasalle (Hymenoptera: Eulophidae: Tetras tichinae) in Argentina. - Revista de Investigaciones Agropecuarias, 37 (2): 159-164.

AYTAR F., 2007 - Description, distribution and hosts of Blastopsylla occidentalis (Homoptera: Psyllidae), a new pest of Eucalyptus spp. in Turkey. - 2nd Plant Protection Congress of Turkey, Isparta, Turkey, 27-29 August 2007, 1: 240 .

Bella S., 2013 - New alien insect pests to Portugal on urban ornamental plants and additional data on recently introduced species. - Annales de la Société entomologique de France (N.S.), 49 (4): 374-382.

BeLla S., 2014 - Invasive insect pests and their associated parasitoids on ornamental urban plants on Corfu island - Phytoliriomyza jacarandae Steyskal and Spencer 1978 (Diptera, Agromyzidae) a new record in Greece. Hellenic Plant Protection Journal, 7: 53-59.

Bella S., Lo Verde G., 2002 - Presenza nell'Italia continentale e in Sicilia di Ophelimus eucalypti (Gahan) $e$ Aprostocetus sp., galligeni degli Eucalipti (Hymenoptera Eulophidae). - Naturalista sicil., 26: 191-197. 
BELLA S., RAPISARDA C., 2013 - First record from Greece of the invasive red gum lerp psyllid Glycaspis brimblecombei Moore (Hemiptera: Psyllidae) and its associated parasitoid Psyllaephagus bliteus Riek (Hymenoptera: Encyrtidae). - Redia, 96: 33-35.

BEN ATTIA S., RAPISARDA C., 2014 - First record of the red gum lerp psyllid, Glycaspis brimblecombei Moore (Hemiptera Psyllidae), in Tunisia. - Phytoparasitica, 42: 535-539.

Bercedo Paramo P., Bahillo de la Puebla P., 1999 Primera cita para Europa de Phoracantha recurva Newman, 1840 (Coleoptera, Cerambycidae). - Est. Mus. Cienc. Nat. Alava, 14: 169-174.

Bouvet J.P.R., BuRCKHARDT D., 2008 - Primer registro para la Argentina de una especie de chicharrita, Ctenarytaina spatulata (Hemiptera: Psyllidae), en plantaciones de eucalipto en Entre Ríos. - Revista de la Sociedad Entomologica Argentina, 67 (1-2): 183-184.

BOUVET J.P.R., HARRAND L., BURCKHARDT D., 2005 - First record of Blastopsylla occidentalis and Glycaspis brimblecombei (Hemiptera: Psyllidae) from Argentina. Revista de la Sociedad Entomologica Argentina, 64 (12): 99-102.

Brennan E.B., Gill R.J., Hrusa F.G., Weinbaum S.A., 1999 - First record of Glycaspis brimblecombei (Moore) (Homoptera: Psyllidae) in North America: initial observations and predator associations of a potentially serious new pest of Eucalyptus in California. - Pan-Pacific Entomologist, 75: 55-57.

BURCKHARDT D., 1998 - Ctenarytaina eucalypti (Maskell) (Hemiptera, Psylloidea) neu für Mitteleuropa mit Bemerkungen zur Blattflohfauna von Eucalyptus. - Mitteilungen der Entomologischen Gesellschaft Basel, 48: 59-67.

BurCKHARDT D., QueIrOz, D.L., 2012 - Checklist and comments on the jumping plant-lice (Hemiptera: Psylloidea) from Brazil. - Zootaxa, 3571: 26-48.

Burckhardt D., Santana D.L.Q., Terra A.L., De Andrade F.M., Penteado S.R.C., Iede E.T., Morey C.S., 1999 - Psyllid pests (Hemiptera, Psylloidea) in South American eucalypt plantations. - Mitteilungen der schweizerischen entomologischen Gesellschaft, 72: 1-10.

CADAHIA D., 1980 - Proximidad e dos nuevos enemigos de los Eucalyptus en España. - Bol. Serv. Plagas, 6 (2): 165-192.

CADAHIA D., 1986 - Importance des insectes ravageurs de l'eucalyptus en région méditarréenne. - OEPP/EPPO Bulletin, 16: 265-283.

CAdAhia D., Ruperez A., 1980 - Posible aparicion de Phoracantha semipunctata Fabr. en Espana, - Bol. Serv. Plagas, 6: 119-122.

Caleca V., Lo Verde G., Maltese M., 2011a - First record in Italy of Psyllaephagus bliteus Riek (Hymenoptera Encyrtidae) parasitoid of Glycaspis brimblecombei Moore (Hemiptera Psyllidae). - Naturalista sicil., ser. IV, 35: 435-444.

Caleca V., Lo Verde G., Rizzo M.C., Rizzo R., 2011b Dispersal rate and parasitism by Closterocerus chamaeleon (Girault) after its release in Sicily to control Ophelimus maskelli (Ashmead) (Hymenoptera, Eulophidae). - Biological Control, 57 (1): 66-73.

Caleca V., Bella S., La Pergola A., Lombardo A., Lo Verde G., Maltese M., Nucifora S., Rizzo R., Suma P., TORTORICI F., RAPISARDA C., 2018 - Environmental factors impact and incidence of parasitism of Psyllaephagus bliteus Riek (Hymenoptera, Encyrtidae) on populations of Glycaspis brimblecombei Moore (Hemiptera, Aphalaridae) in Mediterranean climatic areas. - Redia 101: 89-100. http://dx.doi.org/10.19263/REDIA-101.18.12
Cavalcaselle B., 1982 - Sulla presenza in Italia di uno Psillide nocivo all'eucalitto: Ctenarytaina eucalipti (Maskell). - Cellulosa e carta, 6: 8 pp..

Chauzat M.P., Purvis G., DunNe R., 2002 - Release and establishment of a biological control agent, Psyllaephagus pilosus for eucalyptus psyllid (Ctenarytaina eucalypti) in Ireland. - Annals of Applied Biology, 141: 293-304.

Cillo D., Leo P. \& SeChI D., 2006 - Segnalazioni Faunistiche Italiane. 449. Phoracantha recurva Newman, 1840 (Coleoptera Cerambycidae). - Boll. Soc. entomol. ital., Genova, 138 (1): 77-78.

Conci C., Rapisarda C., TAMAnini L., 1996 - Annotated catalogue of the Italian Psylloidea. Second part (Insecta Homoptera). - Atti dell'Accademia Roveretana degli Agiati, 5B: 5-207.

Costa V., Berti Filho A.E., Wilcken C.F., Stape J.L, LA SAlle J., TeIXEIRA L.DE D., 2008 - Eucalyptus gall wasp, Leptocybe invasa Fischer \& LaSalle (Hymenoptera: Eulophidae) in Brazil: new forest pest reaches the New World. - Rev. Agric., 83 (2): 136-139.

Costanzi M., Malausa J.C., Cocquempot C., 2003 - Un nouveau psylle sur les Eucalyptus de la Riviera Ligure et de la Côte d'Azur. Premières observations de Ctenarytaina spatulata Taylor dans le Bassin Méditerranéen occidental. - Phytoma - La Défense des Végétaux, 566: 48-51.

De QueIroz Santana D.L., Burckhardt D., 2007 Introduced Eucalyptus psyllids in Brazil. - Journal of Forest Research, 12 (5): 337-344.

Dhahri S., Ben Jamaa M.L., Garcia A., Boavida C, BRANCO M., 2014 - Presence of Glycaspis brimblecombei and its Parasitoid Psyllaephagus bliteus in Tunisia and Portugal. - Silva Lusitana, 22 (1): 99-115.

Dzokou V.J., TAMEsse J.L., BurCKhardT D., 2009 Jumping plant-lice of the family Psyllidae (Hemiptera: Psylloidea) from west-Cameroon: biodiversity and host plants. - Journal of Entomology, 6 (1): 1-17.

Garcia A., Figueiredo E., Valente C., Monserrat V.J., BRANCO M., 2013 - First record of Thaumastocoris peregrinus in Portugal and of the neotropical predator Hemerobius bolivari in Europe. - Bull. Insectol., 66 (2): 251-256.

GiLIOMEE J.H., 2011 - Recent establishment of many alien insects in South Africa, a cause for concern. - African Entomology, 19 (1): 151-155.

GREENSLADE A.F.C., 2016 - A new species of eucalyptus psyllid Ctenarytaina spatulata Taylor, 1997 (Hemiptera: Aphalaridae: Spondyliaspidinae) recorded from Great Britain. - Entomologist's Record and Journal of Variation, 128: 265-267.

Grootaert P., Pollet M., Dekoninck W., van AchterBERG C., 2010 - Sampling insects: General techniques, strategies and remarks (pp. 377-399). - In: Eymann J., Degreef J., Hāuser Ch., Monje J.C., Samyn Y., VandenSpiegel D. (editors), Manual on Field Recording Techniques and Protocols for All Taxa Biodiversity Inventories and Monitoring, Abc Taxa, Belgium, $653 \mathrm{pp}$.

Halbert S.E., Gill R., Nisson J.N., 2001 - Two Eucalyptus psyllids new to Florida (Homoptera: Psyllidae). Entomology Circular - Florida Department of Agriculture and Consumer Services - Division of Plant Industry, 407: $1-2$

HODKINSON I.D., 1999 - Biocontrol of eucalyptus psyllid Ctenarytaina eucalypti by the Australian parasitoid Psyllaephagus pilosus: a review of current programmes 
and their success. - Biocontrol News and Information, 20: $129 \mathrm{~N}-134 \mathrm{~N}$

HodKInson I.D., 2007 - A new introduced species of Ctenarytaina (Hemiptera, Psylloidea) damaging cultivated Eucalyptus parvula (= parvifolia) in Europe. Deutsche Entomologische Zeitschrift, 54 (1): 27-33.

Hollis D., 2004 - Australian Psylloidea. Jumping plantlice and lerp insects. - Australian Biological Resources Study, Camberra, Australia: 216 pp..

Hurtado A., Reina I., 2008 - Primera cita para Europa de Glycaspis brimblecombei Moore (Hemiptera: Psyllidae), una nueva plaga del eucalipto. - Bol. Soc. entomol. aragonesa, 43: 447-449.

Ide S.M., Ruiz C.G., Sandoval A.C., Valenzuela J.E., 2011 - Detection of Thaumastocoris peregrinus (Hemiptera: Thaumastocoridae) associated with Eucalyptus spp. in Chile. - Bosque, 32 (3): 309-313 (in Spanish).

JACOBS D.H., NeSER S., 2005 - Thaumastocoris australicus Kirkaldy (Heteroptera: Thaumastocoridae): a new insect arrival in South Africa, damaging to Eucalyptus trees. South African Journal of Science, 101: 233-236.

Karunaratne, W., Edirisinghe, J., RANAWAnA, K., 2010 Rapid survey of damage due to gall wasp infestation in a coppiced Eucalyptus camaldulensis plantation Maragamuwa, Naula in the Matale district of Sri Lanka. - Cey. J. Sci. (Bio. Sci.), 39, S.W. 25, 346: 157-161.

LAUDONIA S., 2006 - Un nuovo psillide su eucalipto. - Inf. agr., 62 (9): 89.

Laudonia S., Viggiani G., Sasso R., 2006 - Parassitoide esotico in aiuto degli eucalipti. - Inf. agr., 61 (40): 74.

LAUDONIA S., GARONNA A.P., 2010 - The red gum lerp psyllid, Glycaspis brimblecombei, a new exotic pest of Eucalyptus camaldulensis in Italy. - Bull. Insectol., 63: 233-236.

LaUdonia S., Sasso R., 2012 - The bronze bug Thaumastocoris peregrinus: a new insect recorded in Italy, damaging to Eucalyptus trees. - Bull. Insectol., 65 (1): 89-93.

lo Verde G., Bella S., Caleca V., Rapisarda C., Sidoti A., 2011 - Presenza in Sicilia di Glycaspis brimblecombei Moore (Hemiptera Psyllidae) su Eucalyptus camaldulensis Dehnh. - Naturalista sicil., ser. IV, 35: 425-434.

Longo S., Palmeri V., Sommariva, D., 1993 - Sull'attività di Avetianella longoi Siscaro, ooparassitoide di Phoracantha semipunctata Fabr. nell'Italia meridionale. - Redia, 76 (1): 223-239.

Malumphy C., Perovic T., Hrncic S., Radonjic S., RAICEVIC M., 2013 - First records of Acizzia jamatonica (Kuwayama) and Glycaspis brimblecombei Moore (Hemiptera: Psyllidae, Aphalaridae) in Montenegro. - Acta Entomologica Serbica, 18 (1/2): 11-15.

Margiotta M., Bella S., Buffa F., Caleca V., Floris I., Giorno V., Lo Verde G., Rapisarda C., Sasso R., Suma P., Tortorici F., Laudonia S., 2017 - Modeling Environmental Influences in the Psyllaephagus bliteus (Hymenoptera: Encyrtidae) - Glycaspis brimblecombei (Hemiptera: Aphalaridae) Parasitoid-Host System. Journal of Economic Entomology, 110 (2): 491-501.

Martinez G., Gómez D., TAYlor G.T., 2014 - First record of the Australian psyllid Blastopsylla occidentalis Taylor (Hemiptera, Psylloidea) from Uruguay. - Transactions of the Royal Society of South Australia, 138 (2): 231-236.

MARTINEZ-Crosa G., 2008 - Thaumastocoris peregrinus Carpintero \& Dellapé, (Heteroptera: Thaumastocoridae): new pest found in Eucalyptus in Uruguay. In IUFRO Recent Advances in Forest Entomology, Pretoria, South Africa, pp 32-33.

Mazza G., Inghilesi A.F., Tricarico E., Montagna M.,
LONGO S., ROVERSI P.F., 2015 - First report of Gonipterus scutellatus complex (Coleoptera Curculionidae) in Sicily (Italy). - Redia, 98: 149-150.

Mazzeo G., Siscaro G., 2007 - Presenza di Phoracantha recurva su eucalipto in Sicilia. - Informatore fitopatol., 3: 35-37.

Mendel Z., Protasov A., Fisher N., La Salle J., 2004 Taxonomy and biology of Leptocybe invasa gen. \& sp. $n$. (Hymenoptera: Eulophidae), an invasive gall inducer on Eucalyptus. - Australian Journal of Entomology, 43: 101113.

Mendel Z., Protasov A., Blumberg D., Brand D., SAPhir N., MADAR Z., LASALlE J., 2007 - Release and recovery of parasitoids of the Eucalyptus Gall Wasp Ophelimus maskelli in Israel. - Phytoparasitica, 35: 330-332.

Mifsud D., Cocquempot C., Mühlethaler R., Wilson M., Streito J.C., 2010 - Other Hemiptera Sternorrhyncha (Aleyrodidae, Phylloxeroidea, and Psylloidea) and Hemiptera Auchenorrhyncha. Chapter 9.4. In: Roques A et al. (eds), Alien terrestrial arthropods of Europe, BioRisk, 4 (1): 511-552.

NoACK A.E., Coviella C.E., 2006 - Thaumastocoris australicus Kirkaldy (Hemiptera: Thaumastocoridae): first record of this invasive pest of Eucalyptus in the Americas. - General and Applied Entomology, 35: 13-15.

Noack A.E., KaApro J., Bartimote-Aufflick K., MAnsfield S., Rose H.A., 2009 - Efficacy of Imidacloprid in the control of Thaumastocoris peregrinus on Eucalyptus scoparia in Sydney, Australia. - Arboriculture \& Urban Forestry, 35: 192-196.

NoAcK A.E., Rose H.A. 2007 - Life-history of Thaumastocoris peregrinus and Thaumastocoris $s p$. in the laboratory with some observations on behaviour. - General and Applied Entomology, 36: 27-33.

Nugnes F., Gebiola M., Monti M.M., Gualtieri L., Giorgini M., WANG J.G., Bernardo U., 2015 - Genetic diversity of the invasive gall wasp Leptocybe invasa (Hymenoptera: Eulophidae) and of its Rickettsia endosymbiont, and associated sex-ratio differences. - PLoS One, 10: e0124660.

O'CONNOR J.P., MALUMPHY C., 2011 - A review of the Irish jumping plant-lice (Hemiptera: Psylloidea). - Irish Biogeographical Society Bulletin, 35: 21-63.

Orousset, J., 1984 - Phoracantha semipunctata $F$., un ravageur des Eucalyptus présent en Corse (Col. Cerambycidae). - Nouv. Rev. Ent., 1: 322.

Ouvrard D., 2017 - Psyl'list - The World Psylloidea Database. - http://www.hemiptera-databases.com/psyllist. Searched on 30 October 2017. doi:10.5519/0029634.

Ouvrard D., BurcKhardT D., COCQUEMPOT C., 2015 - An annotated checklist of the jumping plant-lice (Insecta: Hemiptera: Psylloidea) from the Mercantour National Park, with seven new records for France and one new synonymy. - Zoosystema, 37 (1): 251-271.

Paine T.D., Dahlsten D.L., Millar J.G., Hoddle M.S., HANKS L.M., 2000 - UC scientists apply IPM techniques to new eucalyptus pests. - California Agriculture, 54 (6): 8-13.

PAlmeri V., CAmpolo O., 2006 - Sulla presenza di Phoracantha recurva Newman e Phoracantha semipunctata $F$. (Coleoptera Cerambycidae) in Calabria. - Boll. Zool. agr. Bachic., Ser. II, 38 (3): 251-254.

Pérez-Otero R., Mansilla J.-P., Borrajo P., Ruiz F., 2011 - Primera cita en la Península Ibérica de Blastopsylla occidentalis Taylor (Homoptera: Psyllidae). - Boletin de Sanidad Vegetal, Plagas, 37 (2): 139-144.

Piras L., Contini C., PisAno P., 1970 - Sulla introduzione 
in Europa di un Cerambicide australiano parassita di Eucalyptus: Phoracantha semipunctata Fabr. (Col. Cerambycidae). - Boll. Soc. ent. ital., 102: 58-63.

Protasov A., La Salle J., Blumberg D., Brand D., SAPhir N., Assael F., Fisher N., Mendel Z., 2007 - Biology, revised taxonomy and impact on host plants of Ophelimus maskelli, an invasive gall inducer on Eucalyptus spp. in the Mediterranean Area. - Phytoparasitica, 35 (1): 50-76.

Protasov A., DoĞanlar M., La Salle J., Mendel Z., 2008 - Occurrence of two local Megastigmus species parasitic on the eucalyptus gall wasp Leptocybe invasa in Israel and Turkey. - Phytoparasitica, 36: 449-459.

RAPISARDA C., 1998 - New data on the Sicilian psyllids (Homoptera Psylloidea). - Atti Accademia roveretana Agiati, ser. VII, vol. 8 B: 97-104.

Romano M., 2007 - Nuovi dati sulla presenza in Sicilia di Phoracantha recurva Newman, 1840 (Coleoptera Cerambycidae). - Naturalista sicil., ser. IV, 31 (3-4): 241247.

Reguia K., Peris-Felipo F.J., 2013 - Glycaspis brimblecombei Moore, 1964 (HemipteraPsyllidae) invasion and new records in the Mediterranean area. - Biodiversity Journal, 4 (4): 501-506.

Rizzo M.C., Lo Verde G., Rizzo R., Buccellato V., CALECA V., 2006 - Introduzione di Closterocerus $s p$. in Sicilia per il controllo biologico di Ophelimus maskelli Ashmead (Hymenoptera, Eulophidae) galligeno esotico sugli eucalipti. - Boll. Zool. agr. Bachic. Ser. II, 38 (3): 237-248.

Rizzo M.C., Lo Verde G., Rizzo R., Caleca V., 2015 Risk assessment of non-target effects of Closterocerus chamaeleon (Girault) parasitoid of the eucalypt gall maker Ophelimus maskelli (Ashmead) (Hymenoptera, Eulophidae). - Phytoparasitica, 43(3), 407-415. DOI: 10.1007/s12600-015-0472-3

Romano F.P., CARAPEzza A., 1975 - Sulla presenza di Phoracantha semipunctata Fabr. in Sicilia (Coleoptera Cerambycidae). - Boll. Soc. ent. ital., 107: 91-92.

Rosado-Neto G.H., Marques M.I., 1996 - Characteristics of the adult genitalia and of the immature forms of Gonipterus gibberus and G. scutellatus. - Revista Brasileira de Zoologia, 13: 77-90 (in Portuguese).

RUIZ J.L., BARRANCO P., 1998 - Phoracantha recurva Newman, 1840 nueva specie plaga para la region Mediterranea (Coleoptera Cerambycidae). - Bol. Asoc. Esp. Entom., 22 (1-2): 227-228.

SAma G., Bocchini R., 2003 - Segnalazioni faunistiche: Phoracantha recurva (Newman, 1840) prima segnalazione per la fauna italiana. - Quaderni di studi e notizie di storia naturale della Romagna, 18: 168.

SAPORITO L., 2006 - Problematiche connesse alla utilizzazione forestale in Sicilia di eucalitteti destinati a biomassa ad uso energetico. - Sicilia Foreste, 45: 9-15.

Siscaro, G., 1992 - Avetianella longoi sp. n. (Hyme- noptera: Encyrtidae) egg parasitoid of Phoracantha semipunctata F. (Coleoptera: Cerambycidae). - Boll. Zool. agr. Bachic., Ser. II, 24 (2): 205-212.

Soliman E.P., Wilcken C.F., Pereira J.M., Dias T.K.R., Zaché B., Dal Progetto M.H.F.A., Barbosa L.R., 2012 - Biology of Thaumastocoris peregrinus in different Eucalyptus species and hybrids. - Phytoparasitica, 40: 223-230.

Sopow S., George S., Ward N., 2012 - Bronze bug Thaumastocoris peregrinus: a new Eucalyptus pest in New Zealand. - Surveillance, 39 (2): 43-46.

Spodek M., Burckhardt D., Protasov A., Mendel Z., 2015 - First record of two invasive eucalypt psyllids (Hemiptera: Psylloidea) in Israel. - Phytoparasitica, 43 (3): 401-406.

Suma P., Nucifora S., Bella S., 2014 - New distribution record of the invasive bronze bug Thaumastocoris peregrinus Carpintero \& Dellapé (Heteroptera, Thaumastocoridae) in Italy. - Bulletin OEPP/EPPO Bulletin, 44 (2): 179-182.

TASSI F., 1969 - Un longicorne australiano per la prima volta in Italia (Coleoptera Cerambycidae). - Boll. Ass. romana Entomologia, 24: 69-71.

Teulieres C., Marque C., 2007 - Eucalyptus. In: Pua E.C., Davey M.R. (editors). Biotechnology in agriculture and forestry 60, Transgenic Crops V, Springer, New York: pp. 387-402.

TRIBE G.D., 2003 - Biological control of defoliating and phloem- or wood-feeding insects in commercial forestry in Southern Africa (pp. 113-129). - In: Neuenschwander P., Borgemeister C., Langewald J. (editors), Biological control in IPM systems in Africa, CAB International, Wallingford, UK.

VALENTE C., HodKInSON I.D., 2009 - First record of the Red Gum Lerp Psyllid, Glycaspis brimblecombei Moore (Hem.: Psyllidae), in Europe. - Journal of Applied Entomology, 133: 315-317.

Valente C., Manta A., Vaz A., 2004 - First record of the Australian psyllid Ctenarytaina spatulata Taylor (Homoptera: Psyllidae) in Europe. - Journal of Applied Entomology, 128: 369-370.

Viggiani G., Laudonia S., Bernardo U., $2002-A u$ mentano gli insetti dannosi degli eucalipti.- Inf. agr., 58 (12): 86-87.

WANG Q., 1995 - A taxonomic revision of the Australian genus Phoracantha Newman (Coleoptera: Cerambycidae). - Invertebr. Taxonomy, 9: 865-958.

Wilcken C.F., Soliman E.P., Nogueira de SÁ L.A., Rodrigues Barbosa L.R., Ribeiro Dias T.K.R., Ferreira-Filho P.J., Rodrigues Oliveira R.J., 2010 Bronze Bug Thaumastocoris peregrinus Carpintero \& Dellapé, (Heteroptera: Thaumastocoridae) on Eucalyptus in Brazil and its distribution. - Journal of Plant Protection Research, 50 (2): 201-205. 